\title{
Taxation and Entrepreneurship in a Welfare State
}

\author{
Mikael Stenkula
}




\title{
Taxation and Entrepreneurship in a Welfare State*
}

\author{
Mikael Stenkula
}

June 2009

\begin{abstract}
:
Does tax policy affect the rate of self-employment in a modern welfare state? This question is analyzed empirically based on Swedish data for the entire post-war period. Available tax data indicate that payroll taxes have had a negative influence on the unincorporated rate of self-employment, though the effect is modest. No effects from regular labor income taxation or capital gains taxation are found. The paper improves upon earlier studies in that it tries to separate the effects of different taxes, and uses cointegration techniques. A further extension is that it studies a Scandinavian high-tax welfare state. Earlier time-series studies analyzing selfemployment and taxation have with few exceptions been based on data from countries with relatively low tax levels and less comprehensive welfare systems, notably the US and the UK.
\end{abstract}

JEL-codes: H2, J23, L26.

Keywords: Entrepreneurship, Self-employment, Taxation, Welfare state.

\footnotetext{
* The author thanks Magnus Henrekson, Lars Persson, Niclas Berggren, Johan Almenberg, Robin Douhan and the seminar participants at the Ratio Institute and at the 2008 SEA/SDAE Conference in Washington, D.C. for useful comments and suggestions, Carl Magnus Bjuggren for support with data and Johanna Rickne for help with the econometrics. The usual disclaimer applies. Financial support from the Gustav Douglas Research Program on Entrepreneurship is gratefully acknowledged.
} 


\section{Introduction}

Stimulating entrepreneurship and small business activity has become a priority in developed and developing countries alike. The policy debate often takes up the case of self-employment, a form of small business activity that was largely ignored until quite recently. Earlier, large companies commanded attention.

A variety of factors that can affect the rate of self-employment-including tax structure, the product market and factor market regulations - have been discussed among both academics and policy makers and politicians alike. Anders Borg, Sweden's Minister of Finance, claimed for example that "too high taxes, too generous benefit systems, ineffective labour market policies and too high employers' social security contributions have tended to make labour supply and demand too low...Being an entrepreneur simply has not been sufficiently attractive."

As the tax system is an oft-discussed policy variable that can, at least in theory, be steered by the political system, it deserves consideration within the context of self-employment. ${ }^{2}$ And indeed, a great deal of research has analyzed the connection between self-employment and the tax system. Yet these analyses have failed to produce conclusive results. The empirical analyses have used both differences between countries (cross-section) and over time (timeseries) or a combination of both (panels) to examine this question. Cross-section and country panel data analyses can be a bit problematic as it can be difficult to capture and measure all factors that might differ between countries. ${ }^{3}$ If these factors correlate with the included variables, there will be a bias in the estimations.

On the other hand, a majority of the time-series studies have only analyzed countries such as the United States and the United Kingdom - countries with relatively low taxes as a share of GDP. Yet every country has constructed a distinctive tax and welfare system with its own unique characteristics. As the systems may differ substantially between countries, the effects from taxation may vary as well. Country-specific analyses may therefore give completely different results depending on which country is analyzed.

\footnotetext{
${ }^{1}$ Borg (2008).

${ }^{2}$ See, e.g., Holtz-Eakin (2000) for a discussion of entrepreneurship and tax policy.

${ }^{3}$ It might, e.g., be difficult to capture the differences in labor market systems in one or two variables.
} 
Economists have tried to distinguish between different forms of welfare systems or welfare models, identifying for example the Scandinavian model, the Anglo-Saxon model and the Continental model. The Scandinavian model is characterized by heavy tax obligations, though it also includes generous tax-financed benefits with earnings-related schemes that cover the entire working population. The Anglo-Saxon model is marked by smaller social transfers, which are more targeted and means tested, but also a lower tax burden on the citizens. The taxation of benefits and transfers is normally higher in countries with systems closer to the Scandinavian model (such as Denmark and Sweden) compared to countries whose systems approach the Anglo-Saxon model (such as the US and the UK). ${ }^{4}$ The Continental model is situated somewhere in between these two. ${ }^{5}$

The purpose of this paper is to use Swedish data to see if and how the results differ from other studies. One could expect to find possible effects in a Scandinavian welfare state with a high tax level, as in Sweden. In particular, top payroll taxes have been high in Sweden compared to the United States in the post-war period (table 1).

There are some common problems that should be addressed when self-employment and taxation are empirically analyzed. First, many studies do not attempt to separate the effects of different taxes. Yet different taxes have different effects on self-employment, as Henrekson and Johansson (2009) have shown. Some taxes may stimulate self-employment as a form of tax evasion, whereas other taxes may influence the cost of capital or the organizational form of self-employment. The tax system can also treat the self-employed, wage earners and people outside the labor market very differently. Hence, relying on one tax measure or an aggregate tax measure in an empirical analysis is likely to be misleading. The analysis should be performed at a more detailed level, which this study attempts to do.

Second, when it comes to time-series analysis, many studies do not use cointegration techniques, and thus run the risk of detecting spurious relationships among non-stationary data series. Bruce and Mohsin (2006) conduct the first time-series study that tries to address

\footnotetext{
${ }^{4}$ See, e.g., Adema and Ladaique (2005) and Esping-Andersen (1990).

${ }^{5}$ See Esping-Andersen (1990) for an early discussion about different welfare systems.
} 
these two problems using post-war data from the US. The method of cointegration was first applied to self-employment by Parker (1996), and this approach is used here as well. ${ }^{6}$

In line with Bruce and Mohsin (2006), we find moderate but non-negligible, statistically significant effects of taxation. In other words, Swedish data do not give rise to stronger results-yet important differences do emerge. The US data suggest that mainly the income and capital gains taxation decreases the rate of self-employment. By contrast, the Swedish data suggest that payroll taxes exert the most negative influence.

Two possible explanations for this result are suggested. First, only people inside the labor market pay payroll taxes in Sweden, whereas income tax is also paid by people outside the labor market who receive benefits such as unemployment and pensions. An increase in payroll taxes affects thus the self-employed and wage earners negatively, whereas the effects of an increase in income tax are more neutral. Second, from a statistical point of view, the variance of payroll taxes is much higher in Sweden compared to the US, whereas the opposite is true for income taxes (table 1). Hence, it is not that surprising that a significant effect of payroll taxes is found in Sweden, whereas a significant effect of the income tax is found in the United States.

Previous country-specific analyses have focused primarily on countries related to the AngloSaxon model, while Henrekson (2005) has, in an explorative way, discussed and analyzed entrepreneurship policy in the Swedish welfare state. Yet, to our knowledge, there is no study of taxation and entrepreneurship using a long time-series from a Scandinavian welfare state. This paper aims to fill this gap by studying the case of Sweden. ${ }^{7}$

The paper is organized as follows. In the next section, we present earlier research about selfemployment and taxation. Section three contains a description of the Swedish tax system. The data are described in section four, and the regression results are presented in section five. Section six concludes.

\footnotetext{
${ }^{6}$ Unlike Bruce and Mohsin (2006), Parker (1996) does not focus specifically on the effects of taxation. Parker and Robson (2004) followed up on Parker's paper, however, covering five Western countries and analyzing two tax rates in a more advanced panel cointegration analysis.

${ }^{7}$ Other papers that discuss taxation and entrepreneurship in a Swedish context include Fölster (2002) and Davidsson and Henrekson (2002), but no study has made any extensive post-war econometric analysis as depicted in this study. Ilmakunnas and Kanniainen (2001) have analyzed effects of the welfare state on entrepreneurial activity in a panel including 20 Western countries, but they did not specifically analyze the effects of taxation.
} 


\section{Previous research}

Theoretically, there can be both a positive and a negative relationship between taxation and self-employment. Beside negative incentive effects, one can also think of a positive effect; for example, it may be easier to avoid taxes when one is self-employed. Moreover, selfemployment can also be stimulated if other forms of employment are taxed at a higher rate. ${ }^{8}$ As theory gives ambiguous results, deciding whether the relationship between taxes and selfemployment entails positive or negative effects is ultimately an empirical issue.

Unfortunately, this ambiguity is found in the empirical studies as well.

The empirical literature within this area can be divided into different categories, or "generations". One reasonable division can be made along macro and micro lines. ${ }^{9}$ The macro approach uses some form of aggregate rate of self-employment and tax level variables. Early macro studies used ordinary time-series analysis (OLS with simple correction for potential problems such as autocorrelation), typically finding a positive relationship between taxation and self-employment, i.e., higher taxes raise the rate of self-employment. ${ }^{10}$ The analysis was later extended by including more sophisticated time-series analysis techniques, such as cointegration methods with unit root tests and causality analyses. These studies often found a positive relationship or no relationship at all between self-employment rate and level of taxation. $^{11}$

The micro approach uses individual micro-data, normally organized in panels, to analyze whether changes in tax rates or taxes actually paid affect an individual's decision to become self-employed. ${ }^{12}$ The results from these studies are inconclusive, with both positive and

\footnotetext{
${ }^{8}$ See Long (1982a), Kihlstrom and Laffont (1983), Blau (1987), Parker (1996), Robson and Wren (1999), Gentry and Hubbard (2000) or Cullen and Gordon (2007) for theoretical discussions of self-employment and taxation.

${ }^{9}$ This is not the only way the material can be classified. Bruce and Mohsin (2006) identify three generations, whereas Schuetze and Bruce (2004) divide the empirical literature into four categories.

${ }^{10}$ Examples analyzing US data include Long (1982b) and Blau (1987). Evans and Leighton (1989) use a somewhat different approach, analyzing US self-employment categories based on age, sex and race separately over time with a longitudinal dataset. The results are mixed concerning the effects of taxation.

${ }^{11}$ Examples include Parker (1996) and Robson (1998), who find a positive relationship, and Cowling and Mitchell (1997), who do not find any significant relationship, all using British data. Other more recent analyses that do not find any relationship include Fairlie and Meyer (2000) and Briscoe, Dainty and Millett (2000), using US and British data.

${ }^{12}$ Panel data analysis can also be done on a country level with a more macro approach, such as in Parker and Robson (2004), who find a positive relationship, or Torrini (2005), who finds ambiguous effects. Fölster (2000, 2002) uses a Swedish "cross-county" analysis based on the average tax rate as a share of "regional GDP" or the
} 
negative results reported. Even though this micro approach tries to identify effects at the individual micro data level, it suffers from a clear endogeneity problem as the individual may influence the tax paid. It is also hard to find suitable individual micro-data that cover longer time periods. ${ }^{13}$

\section{Taxation of self-employed workers in Sweden}

The compensation of the self-employed usually comes in the form of wages, dividends, sale of the business or a combination of these. All of these types of compensation can be taxed differently. As a result, the design of the tax system will affect the net amount of these income flows and the incentives of the self-employed. As this article analyzes the Swedish situation, we briefly describe this tax system below, with particular attention paid to the taxation of selfemployed workers. A more detailed description of the tax rates and a discussion of the definition of self-employed can be found in Section 4.

The Swedish tax system has been refashioned over the years, with much change coming after the tax reform in 1990/91. Prior to that reform, Sweden had a global income taxation system, whereby all forms of income, such as income from employment, business and capital, were taxed together. After the reform, Sweden introduced a dual tax system, which involves separate tax schedules for earned income (income from employment and business) and capital income; earned income was taxed progressively but capital income was subject to a proportional tax. Hence, after the tax reform, earned income and capital income were taxed separately. $^{14}$

In Sweden, unincorporated self-employment usually takes one of two forms, either a sole proprietorship (enskild firma) or a limited/unlimited partnership company (kommanditbolag/ handelsbolag). A sole proprietorship can only be held by a single person, and the business is not regarded as a separate legal entity. A partnership company must be owned by at least two persons (or legal entities) and is seen as a legal entity with rights and liabilities. Sole

top marginal income tax rate in the counties. He finds a negative relationship between tax rates and the rate of self-employment.

${ }^{13}$ Examples finding a (mainly) positive relationship include Schuetze (2000), Bruce (2000, 2002), and Cullen and Gordon (2007). By contrast, Moore (2004) and Hansson (2008b) find a negative relationship. Hansson (2008b) uses Swedish data, whereas the others use US, Canadian or British data.

${ }^{14}$ As will be shown later, taxation of capital gains differs from taxation of other capital income. Hence, it will seem plausible to treat it as a category of its own. For a detailed description of the Swedish tax system, see Agell et al. (1998). 
proprietorship and unlimited partnership companies imply unlimited liability for the owner(s). In a limited partnership company, some persons — but not everyone — can have a limited liability. At the beginning of 2008, 540,000 individuals ran their own business as a sole proprietorship and about 70,000 as partnership companies. In other words, a large majority of the unincorporated self-employed ran their businesses as sole proprietorships.

From a taxation perspective, these business forms do not differ in Sweden. The business is not treated as a separate tax subject, and partnership and proprietorship incomes are only taxed at the personal level as business income. It is not possible for the unincorporated self-employed to withdraw an ordinary wage and subsequently tax it as income from employment. The selfemployed must also pay self-employed payroll taxes on the business income. A partnership company can be bought and sold, and the seller(s) has to pay capital gains tax if his share of the company is sold at a profit. A sole proprietorship cannot be sold as it is not considered an independent legal entity.

The self-employed may also incorporate his/her business, which in turn takes the form of a limited company (aktiebolag). If a self-employed person incorporates his/her business, taxation changes dramatically. The corporation is treated as a separate tax subject, meaning that the surplus (profit) is taxed at the company level and a corporate income tax is levied on the net return. The self-employed person in a corporation can withdraw part of his income as a wage. The wage is deductible from the profit, and is not subject to corporate income tax; it is instead taxed as income from employment at the personal level. In addition, the firm has to pay payroll taxes on this income. The incorporated self-employed worker can also take out part of his income as a dividend. In this case, he has to first pay corporate income tax on the profit and then capital income tax on the dividend. That is to say, the incorporated selfemployed worker experiences double taxation in this situation-first a tax at the company level and then one at the owner's level. No payroll taxes are levied on dividends.

Compared to the self-employed person in a sole proprietorship or partnership, the selfemployed person in an incorporated business can decide how much to pay him or herself in wages and how much of the business income to take out as dividend and pay the associated taxes. However, the taxation of incorporated businesses is more complicated. The dual tax system introduced in 1990/91 made it possible to decrease taxes for employees by starting an incorporated business and taking out the income as a dividend with a lower, proportional tax 
rate. To avoid, or at least reduce, this possibility and prevent tax evasion behavior, Sweden introduced special tax legislation that stipulated that dividends (and capital gains) for closely held limited companies (fåmansbolag) above a certain level are to be taxed as income from employment. ${ }^{15}$ It seems reasonable to assume that all incorporated self-employed businesses are closely held. The rules, which are quite complicated, have been changed several times (1994, 1997, 1998, 2006 and 2007). Table 2 provides an overview of the tax system. ${ }^{16}$

\section{Data}

This study requires data on self-employment, taxation and control variables. We will discuss all of these in more detail below. A summary of all data used is provided in table 4.

\subsection{Self-employment data}

The question of who should be defined as self-employed lacks an unequivocal answer. The definition differs over time and between countries. Who should be regarded and defined as self-employed is a matter of what you want to analyze and what phenomena you want to capture. The main difference is whether owners/managers of incorporated businesses should be included in the measure of the self-employed or if only unincorporated owners/managers should be counted.

The measurement and collection of data on self-employment in Sweden can be pursued in a number of ways. Statistics Sweden provides two different measures (from two different sources named AKU and RAMS). However, the measures cover a rather short time period and there have been changes in the definitions, making it impossible to construct long consistent data series. The longest time-series covers 24 years. In addition, Edvinsson (2005) has compiled a unique dataset that incorporates the whole post-war period until 2000. A more detailed description of the statistics can be found in the Appendix, and a summary of the available datasets can be seen in Figure 1 and Table 3.

The number of self-employed is not interesting in itself as the population has changed during the post-war period. Therefore, it is reasonable to calculate and analyze the number of selfemployed as a share of the total labor force. This can be done with all datasets from Statistics

\footnotetext{
${ }^{15}$ A closely-held limited company roughly refers to a limited company that is not listed on a stock exchange and in which four persons (or fewer) own more than 50 percent of the shares.

${ }^{16}$ All tables and figures can be found in the Appendix.
} 
Sweden from 1963 onward. However, no available statistics about the labor force exist from before 1963. As Edvinsson's dataset includes the period 1947-1962 as well, we divide the number of self-employed in his dataset by the amount of the population between 16-64 years.

A problem with self-employment arises in the decision of whether to include the primary sector (agriculture, forestry, hunting and fishing). A large share of self-employment falls within this sector-it comprised almost half of the self-employed at the beginning of the 1960s. The primary sector has, however, been decreasing throughout the post-war period, and only just over 10 percent of the self-employed came from this sector at the beginning of 2000 . This phenomenon has nothing to do with changes in the tax system, and this sector should be excluded from the dataset. ${ }^{17}$ Both the datasets from AKU and Edvinsson allow for exclusion of the primary sector. Unfortunately, it is not possible to exclude the agricultural sector in the publicly available data from RAMS.

\subsection{Tax data}

This section presents the tax data used in our analysis. All taxes during the post-war period have had a certain degree of volatility, which might have influenced the self-employment activity in the economy. The time span includes several minor tax reforms and one major tax reform in 1990/91.

\subsubsection{Tax on earned income (income from business and employment)}

Income from business and employment were taxed together throughout the post-war period, meaning that it is not possible to separate the effects of these two taxes. The higher the tax on these activities, the lower the return of labor as a wage earner and an unincorporated selfemployed. This might discourage business activity in unincorporated form. Part of the income from an incorporated business may be taxed as earned income as well. Hence, it might also discourage incorporated business activity.

In line with Bruce and Mohsin (2006), we use the top marginal income tax rate in the empirical analyses for several reasons. First, it is a simple way to measure the tax level for the self-employed and could work as an acceptable proxy for the maximal tax on the marginal investment. Second, the top marginal tax rates might act as a policy signal affecting the

\footnotetext{
${ }^{17}$ This exclusion is commonly done when analyzing self-employment. No other sector has this clear structural change, and the other sectors are not nearly as big as the agricultural sector, cf. Blanchflower (2000).
} 
aggregate level of self-employment in the economy. ${ }^{18}$ Third, using this approach makes it easier to compare the results with previous studies, in particular with Bruce and Mohsin (2006), who also use top marginal tax rates.

Alternatively, one could use the marginal tax for some arbitrary income level or use marginal tax rates for many different income levels. As we are interested in many different taxes and not only the tax on earned income, this would result in too many tax variables in the end. One could also use some form of aggregated average tax rate, yet this would be cumbersome to estimate; and it is not possible to find suitable data for the whole post-war period. ${ }^{19}$ Even if the top marginal tax rate may not be a perfect tax rate to use, it should be acceptable, and it is also rather easy to determine. ${ }^{20}$

Figure 2 shows the top marginal tax rate on earned income. The tax system formally consists of a proportional local (municipal) income tax and a progressive state income tax composed of several tax brackets. The local income tax rate was deductible until 1971. The local marginal income tax rate has slowly increased during the post-war period from 10 percent to more than 30 percent. The top state marginal income tax was between 50 and 70 percent until the mid-1980s, when it started to decrease; after the tax reform in 1990/91, it was sharply reduced to 20 and then increased to 25 percent. The sum of the local marginal income tax rate and the top state marginal income tax rate - the top marginal income tax-has a hump-shaped pattern; it was about 70 percent until the 1970s, when it increased to about 85 percent. In the beginning of the 1980s there was a formal top marginal income tax cap that restricted the marginal tax rate to 85 percent and later to 80 percent. During the second half of the 1980 s, the tax decreased, and was subsequently sharply reduced by the 1990/91 tax reform.

\subsubsection{Payroll taxes (social security contributions)}

Both income from business (i.e., partnership and proprietorship incomes) and income from employment (wages and salaries) are subject to payroll taxes, whereas corporate income (i.e.,

\footnotetext{
${ }^{18}$ Even if people do not actually pay the highest marginal tax, the tax rate may affect their behavior by, e.g., changing their effort or choice of career, for example.

${ }^{19}$ Effective average income tax rates based on micro data are also a possible alternative; it is used in what we called the "micro approach" in the tax and self-employment literature.

${ }^{20}$ As long as some more appropriate tax rate-whatever that might be — changes and moves in the same way as the top marginal tax rate, the change in the top marginal tax rate may also be seen as appropriate and an acceptable way to analyze how changes in the tax rate affect changes in the rate of self-employment.
} 
the profit from a corporation) is not. ${ }^{21}$ As payroll taxes must be paid on the income from the unincorporated self-employed, high payroll taxes might discourage unincorporated selfemployment or provide an incentive to incorporate the business, as part of the income can be taken out as a dividend. Payroll taxes also make it more expensive for the self-employed to hire employees — independent of business form — which may discourage self-employment. As higher payroll taxes can reduce the net return from working on the labor market while no payroll taxes are paid on welfare benefits or transfers, higher payroll taxes could discourage both wage-earners and the self-employed.

Part of payroll taxes finances the taxpayers' social security benefits, e.g., retirement pensions. But payroll taxes consist of many different taxes and fees and have changed a great deal during the post-war period. They were introduced in 1955, and between 1960 and 1981, the rate was dependent upon income. In our analysis, we use the top payroll tax rate in the same way as we use the top marginal income tax rate. The top payroll tax rate was modest in the beginning but increased moderately during the 1960s to almost 15 percent, then rapidly during the 1970s to about 35 percent. In the 1980s, the taxes decreased slightly. In 2007, the payroll tax rate was 32.42 percent (see Figure 3).

\subsubsection{Capital income taxation}

Capital income taxation is paid by the incorporated self-employed who receive part of their income as dividends. Until 1990/91, capital income was taxed together with and in the same way as earned income, so the tax rate from these incomes applies (Section 4.2.1). After 1991, the capital income was taxed separately at a proportional rate of 30 percent. It was temporarily zero for dividends in 1994 to avoid double taxation but was raised to 30 percent in 1995 again. In 2006 it was decreased to 20 percent for dividends from closely held companies.

As mentioned above, there are special laws that force the self-employed in closely held limited companies to tax part of the dividend as income from employment. Specifically, only a part of the dividend will be taxed as capital income and the residual as income from

\footnotetext{
${ }^{21}$ The payroll taxes on income from business and employment differ to some extent. Normally, the payroll taxes paid on income from business are slightly lower. We abstract from this slight difference and only use the payroll tax rate on income from employment.
} 
employment. ${ }^{22}$ The top marginal tax rate on income from employment is higher than the tax rate on capital income. Since we are interested in the top tax rate, which is probably also the marginal tax rate faced by the self-employed given that income is high enough, the tax rate based on income from employment is the relevant tax rate. ${ }^{23}$ For these reasons, we do not include a specific capital income tax rate in the analysis.

\subsubsection{Capital gains taxation}

The capital gains tax may affect the rate of self-employment as well. First, a higher capital gains taxation lowers the potential net return to suppliers of private equity, making them less likely to invest in the business (together with the self-employed or as a buy-out). Second, it reduces the potential net return to the self-employed himself once he decides to sell his business. ${ }^{24}$ It is important to note that capital gains do not affect sole proprietorship as the business cannot be sold as its own entity; assets sold from the business are taxed as business income.

Until the 1990/91 tax reform, capital gains were taxed together with all other income (as described in Section 3). However, only parts of the capital gains were taxable, depending on how long the owner had held his or her asset (e.g., your own company shares). The longer one had owned the asset, the smaller the part of the taxable gain was taxable. The rules about how large of a share was exempted from taxation changed several times during this period. All capital gains on assets held less than two years have, however, been subject to taxation during the whole period.

Following the 1990/91 tax reform, capital gains were taxed as capital income at their full value, independently of how long the owner had owned the asset. Capital income was taxed at a proportional rate of 30 percent as described above. In 1994, the tax rate was temporarily lowered to 12.5 percent for capital gains. However, closely held limited companies, in contrast to partnerships, had special rules after the 1990/91 tax reform; half of the capital

\footnotetext{
${ }^{22}$ No payroll taxes have to be paid on this income.

${ }^{23}$ A more correct description would be that a closely held company will not pay out (more) dividends if it will be taxed as income from employment but will instead take out the surplus as wage. The income will still be taxed as income from employment in this way, but one avoids corporate income tax and pay payroll taxes instead. These taxes will be about the same, but the payroll taxes will also provide some social security benefits. A part of the income from an unincorporated self-empoloyed may also be taxeds as capital income (räntefördelning). This will decrease his average tax.

${ }^{24}$ Of course, high capital gains taxation might discourage investments in general — not only investments in selfemployment activities — and therefore decrease the total available capital in the economy.
} 
gains were taxed as true capital gains and half as income from employment if one sold one's own company. In 2006, the rules for closely held limited companies were temporarily changed, which implied that the top marginal tax rate was as high as the tax rate on income from employment.

As the capital gains taxation depended upon how long you had owned the company until 1991, there is no obvious way to state how high the capital gains taxation was during the postwar period. Figure 4 shows how the capital gains tax for selling a partnership or limited company has evolved over time. Two graphs show the top tax rate before 1991, one for longterm possessions (more than five years) and one for short-term possessions (less than two years). From 1991 onward, another two graphs illustrate the top capital gains tax for limited and partnership companies, which now begin to differ. The short-term graph is identical to the top marginal income tax rate depicted in Figure 2. The long-term tax increased sharply in 1966 and in 1976. During the 1980s, there was a slight decrease as with the ordinary top marginal income tax. After the tax reform, when there was no difference between long-term and short-term possessions, the long-term tax rate increased and the short-term tax rate decreased. In 1994, there was a sharp but short-lived reduction, and in 2006 a sharp but shortlived increase, in the tax rate for incorporated businesses.

\subsubsection{Corporate income taxation}

The corporate income tax is only paid by the incorporated self-employed (at the company level) and may thus negatively influence the net return on incorporated self-employment. ${ }^{25}$ As with the income taxation, we use the highest marginal tax rate.

Figure 5 tracks the development of the corporate income tax in the post-war period. Until 1984, the corporate income tax consisted of two parts: a state corporate income tax and a local (municipal) corporate income tax. Both taxes were proportional. ${ }^{26}$ The state corporate income tax during this time was usually 40 percent. The local corporate income tax was deductible and as high as the corresponding personal local income tax; it was also changed yearly.

\footnotetext{
${ }^{25}$ This is actually not completely true. Currently, the system also allows the unincorporated self-employed to tax a small part of their income as if it were a corporate income.

${ }^{26}$ The state corporate income tax was progressive before World War II.
} 
In 1985, the local corporate income tax was abolished and the state corporate income tax was increased to 52 percent. The tax rate was reduced to 30 percent after the tax reform of 1990/91 and to 28 percent in 1994. However, there existed numerous options to significantly decrease the effective corporate income tax rate through generous tax-deductible and appropriation possibilities before 1990/91. These possibilities were most generous to large and old companies—not to the self-employed.

\subsubsection{Wealth taxation}

A new wealth tax was introduced in $1947 .{ }^{27}$ This tax had to be paid by households if the assessed value of their assets reached above a certain threshold. This implied that the wealth tax had to be paid by the owner of a company if the value of the company was high enough (together with the assessed value of all other taxable personal assets). In 1991, the wealth tax on non-listed companies, including companies owned by the incorporated self-employed, was abolished. Despite wealth tax being levied between 1947 and 1991, there is no straightforward way to calculate the top tax rate. To avoid arbitrary assumptions, we will not include any tax rate in the econometric analysis. The wealth tax may nonetheless influence the level of selfemployment in the economy, and the abolition of the wealth tax should at least be included in the analysis. ${ }^{28}$ Hence, we include a dummy to take into account the existence and abolition of the wealth tax on non-listed companies.

\subsection{Control variables}

To accurately analyze the tax effects on the rate of self-employment in a regression, it is necessary to account for control variables and the changes in other factors that might influence self-employment in the economy. We will use a standard set of control variables as suggested by Bruce and Mohsin (2006) to control for changes in, for example, labor market and macroeconomic conditions. The set of controls includes the following:

- GDP growth, to capture macroeconomic fluctuations

- The interest rate, to capture other macroeconomic effects and borrowing costs

- Average wage, to capture effects of the hiring environment and the potential economic compensation that is forgone by the self-employed

\footnotetext{
${ }^{27}$ Before 1947, part of one's wealth was treated as income and was added to one's earned income subject to income tax.

${ }^{28}$ See Hansson (2008a) for an analysis of the effect of the abolition of the wealth tax on the rate of selfemployment in some Western countries.
} 
- Unemployment rate, to capture the propensity to engage in so-called necessity entrepreneurship

- Female participation rate, to capture gender differences

- Service sector share, to capture business structure differences

- Average age of the labor work force, to capture age differences and demographic changes

- Stock of wealth, to capture wealth effects

- Dummy for non-social-democratic governments, to capture potential political effects on business climate that are not connected to tax changes.

GDP growth and the interest rate are standard in almost all regressions and are straightforward to measure. As the main alternative to being self-employed is regular paid work, the average wage thus works as a proxy of the opportunity cost of self-employment. Higher average wages make it less favorable to go from a wage income to being selfemployed, but may also make the hiring environment faced by a self-employed individual harsher. ${ }^{29}$ The average wage in the manufacturing and extractive industries is available for every year since 1975 and about every fifth year since 1947 from Statistics Sweden. We use linear interpolation when data is missing between 1948 and $1974 .{ }^{30}$

According to almost all descriptive statistics of self-employment, women have been much less likely to start or run their own businesses. As a result, it may be important to control for gender changes in the labor force. Unfortunately, it is not possible to find data on gender participation rates before 1963. In addition, the possibility of being self-employed depends on the industry in which one works or wishes to start a business. Workers in the service sector have a much higher possibility of becoming self-employed. The employment share of the service sector is included to account for changes in the business structure. The probability that individuals discover self-employment opportunities may increase with experience. To capture this effect, we include the average age of the population. Wealthier persons are more likely to start businesses, and the stock of wealth should thus be included as well. Unfortunately, it is

\footnotetext{
${ }^{29}$ The legislated minimum wage is included in some studies instead of the average wage. Sweden, however, has no minimum wage laws that can be directly influenced by the government. Instead, wage setting is mainly performed by collective agreement negotiated by the trade unions. No one has systematically collected data about this as far back as 1947.

${ }^{30}$ Although the wage in manufacturing may not be ideal for capturing the opportunity cost for the potential selfemployed, it is nevertheless the best measure available.
} 
not possible to find a homogeneous dataset describing some form of private wealth for the whole period. Instead, two different sources covering different time periods exist; these cannot be merged but can be used separately when possible. Some studies also include dummies to take into account changes in the government and the ruling party/parties. We have included a dummy for non-social-democratic governments. This will hopefully avoid the greatest potential biases from omitted variables. The formal definitions of the control variables, as well as the data sources, are listed in Table $5 .^{31}$

Two interrelated problems emerge when working with these kinds of macroeconomic timeseries data. First, some of the control variables are not derived from any microeconomic theoretical model of individual utility maximizing behavior. Second, there might be a causality and endogeneity problem among some of the control variables. For example, there are no existing microeconomic models analyzing the choice to become self-employed that include the service sector share, and it is not obvious what such a model would look like. ${ }^{32}$ An increase in the number of self-employed may also increase the service sector share, as it is more likely for workers to become self-employed in this sector; i.e., the causality could go in both directions.

\section{Analysis}

First, we do ordinary regressions with all five time-series of self-employment and all possible tax and control variables presented in Section 4. These regressions are done in levels with a time trend as in Bruce and Mohsin (2006) and with robust standard errors. We also use the usual "rule of thumb" and keep years, proportions and percent unlogged but log variables in currency units, such as wage and wealth. The results are displayed in Table 6.

\footnotetext{
${ }^{31}$ There are some control variables that we were unable to include. The share of the population that has completed high school is often added as a control variable in this kind of analysis to take educational differences into account. It is, however, not possible to find any suitable Swedish data about this. Another possible control variable could be the number of people with a foreign background, as the proportion of self-employed usually is higher among this group. We have not been able to find such data. However, immigration data is easily available, but this flow variable should not be used to analyze the level of self-employment but rather the change in self-employment. Furthermore, immigrants are a rather heterogeneous group.

${ }^{32}$ It is, however, not unreasonable to assume that entry into self-employment requires some outlays and that these outlays are smaller within the service sector due to, e.g., lower MES within this sector. An exogenous change of the demand pattern toward low MES sectors may thus increase the possibility of becoming selfemployed.
} 
As can be seen from the table, the tax effects-including level, direction and significance — differ between the datasets. All effects are economically small, and most of them are not statistically significant. In Dataset $\mathrm{C}$, the majority of the control variables are significant and have the right sign. The same can be said about Dataset E, with the exception of the wage rate. In the other datasets, especially in Datasets B and D, no or very few control variables are significant. Thus, drawing reliable general conclusions based on these regressions seems doubtful. Sample $\mathrm{C}$ is the most interesting subset as it is much larger than the other samples. ${ }^{33}$ The other datasets are small and the degrees of freedom are low. We drop these regressions from further analysis.

From this point forward, we continue the analysis based solely on Dataset $\mathrm{C}$, which describes the rate of unincorporated self-employment. The regression based on Dataset $\mathrm{C}$ shows a small negative effect from the corporate income tax rate and the payroll tax rate. The regression has, however, a rather low Durbin-Watson statistic, but passes the Ramsey RESET test for misspecification error. The high R-squared may indicate problems with stationarity and spurious regression. To check for this, we start by using the standard Augmented Dickey Fuller (ADF) test to test for stationarity and unit roots. The main results can be seen in Table 7, which indicates that almost all variables are non-stationary in levels but stationary in first differences, i.e., the variables are I (1). The only exceptions are GDP growth, which is stationary in levels, and age, which is stationary in second differences. ${ }^{34}$ Including a trend in the ADF test does not alter the result. ${ }^{35}$

A normal procedure in this case could be to rerun the regression in first differences. However, we act in line with Bruce and Mohsin (2006) and use cointegration technique, which makes it possible to take into account the problem with non-stationarity but also find and separate long-run equilibrium relationships from short-run relationships. In other words, one can extract more information about any possible relationship.

The starting point of the analysis is to identify the variables that we would like to include in the cointegration analysis. By rerunning the initial regression (with subset $\mathrm{C}$ ) and successively

\footnotetext{
${ }^{33}$ The time length can be compared with Bruce and Mohsin (2006), who analyze the time period from 1950 to 2000, and Parker (1996), who analyzes the time period from 1959 to 1991.

${ }^{34}$ GDP growth is, however, the first difference of GDP. It is usually assumed that the growth rate influences the level of self-employment.

${ }^{35}$ The stationarity has also been checked with the Phillips-Perron (PP) test with the same results (not shown in any table).
} 
removing (the most) non-significant variables, we end up with the model specified in Table 8 . As can be seen from the table, the corporate income tax and payroll taxes are still the only tax variables that seem to matter, and the size effect is somewhat larger compared to the original regression. The significant control variables have about the same size effect as in the original regression. Now we want to analyze if these variables influence the rate of self-employment in the long- and/or short-run. In the analysis we must, however, exclude dummies as it is not possible to include them in a normal cointegration analysis.

Before doing the formal estimation, we have to specify three things: (1) the number of lags, (2) the trend specification and (3) the number of cointegrating vectors. The number of lags is set to 1 according to Schwarz's Bayesian information criterion, and we will allow for the inclusion of a constant in both the short- and long-run relationships. The number of cointegrating vectors is decided by applying the Johansen-Juselius' cointegration test. The testing procedure includes two different tests, the maximum eigenvalue test and the trace test. Both of these tests reject the hypothesis of no cointegration, i.e., there seems to exist long-run relationship(s) in our data between (some of) our variables. However, the trace test shows (max) four cointegrated vectors, but the maximum eigenvalue test shows only one cointegrated vector (see Table 9). The trace test is very sensitive to the specification of the model, i.e., whether or not constants or trends are included in the relationship. The maximum eigenvalue test is, on the other hand, more stable, indicating that there exists one cointegrated vector, independent of specification. ${ }^{36}$ We continue our analysis by assuming one cointegrating vector, which seems reasonable given the theory and will make the analysis much simpler. ${ }^{37}$

The normalized cointegrated vector-i.e., the possible long-run relationship — is presented in Table 10. The relationship is similar to the relationship found in Table 8. The corporate income tax and payroll taxes still have a negative, statistically significant effect. The effects are somewhat larger, but are still rather small. A ten percentage point decrease in the payroll

\footnotetext{
${ }^{36}$ Not shown in any table. Furthermore, the null hypothesis in the Maximum Eigenvalue test is that there are exactly $r$ cointegrating vectors, whereas the null hypothesis in the Trace test is that there are at most $r$ cointegrating vectors. The tests in Table 8 show, hence, that we cannot reject the hypotheses that there are exactly one and at most four cointegrating vectors, which is not a contradiction.

${ }^{37}$ In line with Parker (1996), we can also say that the coefficients from the other possible cointegration vectors are not plausible.
} 
tax rate will increase the rate of self-employment by about 0.3 percentage points. ${ }^{38}$ The corporate income tax has a much smaller effect (about 0.1 percentage points' change instead of 0.3). Among the control variables, the wage rate and the interest rates have highly significant effects at about the same level as in the ordinary OLS regression. The effects from the service sector and unemployment rate are smaller than before. The effect from the service sector is still highly significant, but the unemployment rate is no longer significant. All of the statistically significant effects have the expected signs.

As most unincorporated self-employed individuals do not pay corporate or capital gains taxes, it is not strange that no or only very small effects are found for these taxes. The most interesting conclusion from the analysis is instead that the regular income tax does not seem to have affected the rate of self-employment in the economy, whereas payroll taxes have.

One explanation for this result might be that people outside the labor market are affected by the income tax but not by payroll taxes as they have to pay income tax, but no payroll taxes, on the benefits they receive. ${ }^{39}$ An increase in payroll taxes may thus negatively affect the selfemployed (and the wage-earners), whereas an increase in the income tax is more neutral between different categories in the population. ${ }^{40}$ In a welfare state with taxable benefits and transfers, payroll taxes may be more negative for the self-employment level than the income tax. The theoretical underpinning for this idea and a more thorough empirical test for this possible effect will be left for future research. ${ }^{41}$

The short-run relationship, including an error-correction term showing the adjustment to the long-run equilibrium level, can be identified using the results from the cointegration analysis above. The error-correction model with the self-employment rate as the dependent variable is displayed in Table 11. Most importantly, the error-correction term is highly significant and negative, implying that there exists a long-run relationship and an adjustment process toward

\footnotetext{
${ }^{38}$ During the post-war period, the average self-employment share of the population between 16 and 64 years has been about 4.5 percent; this corresponds to an increase of almost 7 percent.

${ }^{39}$ In 1974, unemployment insurance benefits became taxable.

${ }^{40}$ The analysis can be extended to examine how the self-employed, as a share of the employed persons, are affected by taxes, i.e., ignoring the non-employed. Payroll taxes do, however, still have a significant negative effect on the rate of self-employment; i.e., if this explanation were true, payroll taxes must also affect the selfemployed more negatively than wage-earners.

${ }^{41}$ It is often assumed that payroll taxes have no effect on the employment level in the economy as the incidence of the payroll taxes is fully on the wage-earner in the long-run (see Section 3 in Bennmarker et al. [2008] for empirical studies related to the Nordic countries). Recent studies on Swedish data indicate, however, that there might be an employment effect due to an increase in the number of firm entries (and decrease in the number of firm exits) when payroll taxes are decreased (Bennmarker et al. 2008). Most people who start a new business will be self-employed. The result in this paper may, hence, have captured this effect.
} 
it. The coefficient is a bit higher than 0.25 , indicating that it will take approximately 2 to 2.5 years for the rate of self-employment to change halfway to a new long-run equilibrium level. The self-employment rate will, hence, adapt slowly to changes in, for instance, the tax rates; i.e., there is no quick fix for politicians if they want to stimulate the self-employment rate through tax changes. In the same way, tax increases will only slowly discourage people from self-employment. This makes sense as most people will not instantaneously start or stop being self-employed due to changes in the economic environment in the presence of, e.g., adjustment costs for switching between sectors. ${ }^{42}$ Except from the error-correction term, only the lagged self-employment in first difference is significant. Hence, there seems does not seem not to be any short-run effects in the self-employment rate due to tax changes (or any of the other control variables included in the model). The whole model is significant, however, with a chi-squared value of 25.53 and a $p$-value of 0.0024 .

In order to test the robustness, we have done the analysis for other specifications as well. On the whole, the results are the same for the key variables (the tax variables and the errorcorrection term). Using the Lagrange multiplier test for autocorrelation, we do not find any evidence for the existence of autocorrelation in the model. However, the model does not pass the Jarque-Bera test for normality. ${ }^{43}$ This might suggest that there is more information about the relationship that has not been extracted from the residuals; i.e., there may exist other explanatory variables that could — and should — be included in the analysis. ${ }^{44}$ In our model estimation, we have excluded two dummy variables, as stated above. These variables can be included in the model as "exogenous" variables, excluded from the long-run relationship but added separately in the error-correction specification. The main results (the effect of taxation and the error-correction term) will be about the same, and this model specification passes the Jarque-Bera test for normality. ${ }^{45}$

The results derived above can be compared with the analysis of US data in Bruce and Mohsin (2006), who also find statistically significant but small effects of taxation on the rate of selfemployment. However, they found a negative effect of the income tax, but no clear effect of

\footnotetext{
${ }^{42}$ This fairly slow error-correction behavior in the rate of self-employment is also found in Parker's (1996) analysis of the UK, which estimates the error-correction term to be about -0.22 .

${ }^{43}$ These results are not shown, but they are available on request from the author.

${ }^{44}$ The same problem is present in Lindquist and Vilhelmsson's (2006) cointegration analysis. They increase the lag length to take this into account.

${ }^{45}$ Not shown in any table. We could also increase the lag length, as in Lindquist and Vilhelmsson (2006), to solve this problem. The model fit will, however, be worse with this approach.
} 
payroll taxes. ${ }^{46}$ As stressed in the introduction, it might be easier to find effects of taxation if tax rates are high, and this idea is confirmed when it comes to payroll taxes-Swedish payroll taxes have on average been about twice as high as in the US during the post-war period. No effect is found of the Swedish income tax rate, though the average tax rate has been slightly higher in Sweden. However, the variance of this tax has been substantially higher in the US, which may explain the differences. Bruce and Mohsin (2006) also found small but significantly negative effects of capital gains taxation, which were not found in the Swedish data. As discussed above, the majority of the unincorporated self-employed in the Swedish sample are not affected by capital gains taxation. The incorporated self-employed must be analyzed in order to say anything relevant about this tax.

Although effects from payroll taxes were found, one must nevertheless conclude that neither more nor stronger effects have been found in the Swedish data compared to Bruce and Mohsin's (2006) US data. One reason, as stated above, is that the analysis did not include the incorporated self-employed. It may also be difficult to capture possible tax effects econometrically in macro data, even if more advanced time-series techniques are used. Although this study has analyzed the tax system in more detail, it is hard — if not impossible - to capture the whole complexity of a tax system in an econometric analysis. Other forms of tax measures could also be used, which might alter the results. With longer time-series in the future, it will be possible to do a more complete analysis based on the incorporated self-employed as well as using individual micro data.

\section{Conclusion}

This paper has analyzed if and how tax policy has influenced the rate of self-employment in Sweden after World War II. Three extensions from previous empirical time-series analyses have been made. First, the paper tries to separate the effects of different taxes and, second, a cointegration technique is used. This paper has, as a third extension, analyzed Sweden, i.e., a Scandinavian welfare state with a relatively high tax level as a share of GDP. In contrast, previous time-series studies analyzing self-employment and taxation have usually been based on data from countries with relatively low tax levels and with a less substantial welfare system, such as the US and the UK.

\footnotetext{
${ }^{46}$ Parker and Robson (2004) also found a very small but significant negative effect of payroll taxes in a panel covering twelve countries, including both Sweden and the US.
} 
This paper finds small but significant negative effects of payroll taxes, but no effects of the income tax. There are several possible explanations for this. One reason may be that the income tax affects most people, both insiders and outsiders, whereas payroll taxes affect only insiders, i.e., the self-employed and wage-earners. However, more theoretical as well as empirical research needs to be done to analyze these questions further. A second reason may be purely statistical: the variance of payroll taxes has been much higher than the variance of the income tax, making it easier to find a significant effect of payroll taxes. This paper finds, further, only small or no effects from corporate taxation and capital gains taxation. Yet these taxes do not directly affect the unincorporated self-employed; these results should thus not be unexpected.

Our results can be compared with those of Bruce and Mohsin (2006), who mainly find a statistically significant but small negative effect of income and capital gains taxes, as well as of corporate income taxation, in the US data. One reason that clear-cut effects from payroll taxes were found for Sweden but not for the US may be that Swedish payroll taxes have been about twice as high as those in the US. The variance of the income tax has, on the other hand, been much higher in the US, which may explain why significant effects were found from the income tax in the US data.

From a policy point of view, the paper underlines the importance of looking at the design of the tax system. Not only the aggregate level of taxation matters for the entrepreneurial spirit and the economy, but also what is taxed and who is taxed. An increase or decrease in one tax rate may affect only part of the population or affect various groups differently, which may unintentionally dampen entrepreneurial activity in a country or distort the economy. 


\section{Appendix}

\section{Swedish self-employment data}

The most commonly used measure of self-employment in Sweden comes from Statistics Sweden (SCB), which has conducted a Labor Force Study, LFS (AKU in Swedish), since 1960. This is an individual-based sample survey that, among other things, measures the number of self-employed. Unfortunately, their definition of self-employment was changed in 1987 to include incorporated self-employed in the data. Previously, only unincorporated selfemployed were included. ${ }^{47}$ Besides LFS, there is a labor statistics dataset based on administrative sources, RAMS, which is a total survey and gets its information based on records of personal tax returns. The main obstacle with this dataset is that data for unincorporated and incorporated self-employed are available only from 1985 and 1989, respectively, and only the self-employed with a business surplus (profit) were included until 2003 (excluding approximately 60,000 businesses in 2003). ${ }^{48}$

The data of RAMS and AKU are supposed to be fairly comparable, although the latter is only a survey. The largest difference between the datasets refers to the number of self-employed, which is higher in AKU than in RAMS. ${ }^{49}$ One reason for this is that AKU includes unpaid family workers (approximately at most 15,000 during the 1980s and 1990s) and that RAMS only included businesses with a surplus until 2003, as stated above. Another reason may be that AKU is based on survey responses, whereas RAMS is based on what is actually reported to the tax authority. People may be too eager to define themselves as self-employed in surveys, even if they should not be regarded as self-employed. ${ }^{50}$ It is, unfortunately, not possible to merge the data from AKU with RAMS. The differences between the datasets are too large.

\footnotetext{
${ }^{47}$ In 1986, self-employment was measured both with and without incorporated self-employed, and the number of incorporated self-employed was estimated to be about 120,000 . Only the total number of self-employed is reported thereafter.

${ }^{48}$ Besides these official statistics, there exist database sources from Statistics Sweden, including FRIDA (Företagsregister och individdatabas) and LINDA (Longitudinal Individual Database), which can be used to analyze self-employment and taxation from an individual micro perspective in panels. These datasets are, however, not appropriate here.

${ }^{49}$ In 2006, AKU reported about 50,000, or 12.5 percent, more self-employed, including both unincorporated and incorporated businesses and unpaid family owners. In 1989, the first year when data about both unincorporated and incorporated self-employed exist in RAMS, the difference was about 80,000 or 25 percent.

${ }^{50}$ SCB (2006). This can be particularly true when a person has two occupations - a hired occupation and their own business - where RAMS has explicit rules for when one is supposed to be defined as self-employed, whereas it is up to one's own judgement if one is asked to state one's (main) occupation as in AKU.
} 
There is another alternative for analyzing the number of unincorporated self-employed in Sweden that is not directly taken from the official datasets from Statistics Sweden and that covers a longer time period. Edvinsson (2005) presents a range of long-term data sets from the mid $19^{\text {th }}$ century to 2000 , including data on self-employment. The data after World War II should be usable and are based on figures from the National Accounts

(Nationalräkenskaperna). ${ }^{51}$

\footnotetext{
${ }^{51}$ A detailed description of this dataset can be found in Edvinsson (2005).
} 


\section{References}

Adema,Willem and Ladaique, Maxime (2005). "Net Social Expenditure, 2005 edition, More Comprehensive Measures of Social Support." OECD Social, Employment and Migration Working Papers No. 29.

Agell, Jonas, Englund, Peter and Södersten, Jan (1998). Incentives and Redistribution in The Welfare State. The Swedish Tax Reform. London: MacMillan Press.

Bennmarker, Helge, Mellander, Erik and Öckert, Björn (2008). "Do Regional Payroll Tax Reductions Boost Employment?” IFAU Working Paper No 2008:19.

Blanchflower, David G. (2000). "Self-Employment in OECD Countries." Labour Economics, vol. 7(5), pp. 471-505.

Blau, David M. (1987). “A Time-Series Analysis of Self-Employment in the United States.” Journal of Political Economy, vol. 95(3), pp. 445-467.

Borg, Anders (2008). "Re-establishing the Swedish Model." Speech by Anders Borg, Minister of Finance, at The Economist's Business Roundtable with the Government of Sweden.

Briscoe Geoff, Dainty, Andrew and Millett, Sarah (2000). "The Impact of the Tax System on SelfEmployment in the British Construction Industry." International Journal of Manpower, vol. 21(8), pp. 596-614.

Bruce, Donald (2000). "Effects of the United States Tax System on Transitions into SelfEmployment." Labour Economics, vol. 7(5), pp. 545-574.

Bruce, Donald (2002). "Taxes and Entrepreneurial Endurance: Evidence from the Self-Employed." National Tax Journal, vol. 55(1), pp. 5-24.

Bruce, Donald and Mohsin, Mohammed (2006). "Tax Policy and Entrepreneurship: New Time-series Evidence.” Small Business Economics, vol. 26(5), pp. 409-425.

Cowling, Marc and Mitchell, Peter (1997). "The Evolution of UK Self-Employment. A Study of Government Policy and the Role of the Macroeconomy." The Manchester School, vol. 65(4), pp. 427-442.

Cullen, Julie Berry and Gordon, Roger H. (2007). "Taxes and Entrepreneurial Risk-taking: Theory and Evidence for the U.S." Journal of Public Economics, vol. 91(7-8), pp. 1479-1505.

Davidsson, Per and Henrekson, Magnus (2002). "Determinants of the Prevalence of Start-Ups and High-Growth Firms.” Small Business Economics, vol. 19(2), pp. 81-100.

Edvinsson, Rodney (2005). Growth, Accumulation, Crisis: With New Macroeconomic Data for Sweden 1800-2000. Stockholm: Almqvist \& Wiksell International.

Englund, Peter (1993). “Den gynnande bostadssektorn.” In Werin, Lars, Englund, Peter, Jonung, Lars, Wihlborg, Clas (eds.) Från räntereglering till inflationsnorm, Stockholm: SNS Förlag.

Esping-Andersen, Gøsta (1990). The Three Worlds of Welfare Capitalism. Cambridge, UK: Polity Press.

Evans, David S. and Leighton, Linda S. (1989). "The Determinants of Changes in U.S. SelfEmployment, 1986-1987.” Small Business Economics, vol. 1(2), pp. 111-119.

Fairlie, Robert W. and Meyer Bruce D. (2000). "Trends in Self-Employment Among White and Black Men During the Twentieth Century." Journal of Human Resources, vol. 35(4), pp. 643-669.

Fölster, Stefan (2000). ’Do Entrepreneurs Create Jobs?" Small Business Economics, vol. 14(2), pp. $137-148$.

Fölster, Stefan (2002). “Do Lower Taxes Stimulate Self-Employment?” Small Business Economics, vol. 19(2), pp. 135-145

Gentry, William M. and Hubbard, Glen R. (2000). "Tax Policy and Entrepreneurial Entry.” American Economic Review, vol. 90(2), pp. 283-287.

Hansson, Åsa (2008a), "The Wealth Tax and Entrepreneurial Activity.” Journal of Entrepreneurship, vol. 17(2), pp. 139-156.

Hansson, Åsa (2008b). "Income Taxes and the Probability to Become Self-employed: The Case of Sweden.” Ratio Working Papers No 122. 
Henrekson, Magnus (2005). "Entrepreneurship: A Weak Link in the Welfare State." Industrial and Corporate Change, vol. 13(3), pp. 437-467.

Henrekson, Magnus and Johansson, Dan (2009). "Competencies and Institutions Fostering Highgrowth Firms." Foundations and Trends in Entrepreneurship, vol. 5(1), pp. 1-82.

Holtz-Eakin, Douglas (2000). "Public Policy toward Entrepreneurship." Small Business Economics, vol. 15(4), pp. 283-291.

Ilmakunnas, Pekka and Kanniainen, Vesa (2001). "Entrepreneurship, Economic Risks and Risk Insurance in the Welfare State: Results with OECD Data 1978-93." German Economic Review, vol. 2(3), pp. 195-218.

Kihlstrom, Richard E. and Laffont, Jean-Jacques (1983). "Taxation and Risk Taking in General Equilibrium Models with Free Entry.” Journal of Public Economics, vol. 21(2), pp. 159-181.

Lindquist, Matthew J. and Vilhelmsson, Roger (2006). "Is the Swedish Central Government a Wage Leader?" Applied Economics, vol. 38(14), pp. 1617-1625.

Long, James E. (1982a). “The Income Tax and Self-Employment.” National Tax Journal, vol. 35(1), pp. 31-42.

Long, James E. (1982b). "Income Taxation and the Allocation of Market Labor." Journal of Labor Research, vol. 3(3), pp. 259-276.

Moore, Kevin B. (2004). "The Effects of the 1986 and 1993 Tax Reforms on Self-Employment." FEDS Working Paper No. 2004-05.

Parker, Simon C. (1996). “A Time-series Model of Self-employment under Uncertainty." Economica, vol. 63(251), pp. 459-475.

Parker, Simon C. and Robson, Martin (2004). "Explaining International Variations in SelfEmployment: Evidence from a Panel of OECD Countries." Southern Economic Journal, vol. 71(2), pp. 287-301.

Robson, Martin T. and Wren, Colin (1999). "Marginal and Average Tax Rates and the Incentive for Self-Employment.” Southern Economic Journal, vol. 65(4), pp. 757-773.

Robson, Martin T. (1998). "The Rise in Self-Employment amongst UK Males.” Small Business Economics, vol. 10(3), pp. 199-212.

SCB (2006). "Ny källa till företagarpopulationen i den registerbaserade arbetsmarknadsstatistiken (RAMS)." Report from Statistics Sweden 2006-11-21.

Schuetze, Herbert J. (2000). "Taxes, Economic Conditions and Recent Trends in Male SelfEmployment: Canada-U.S. Comparison.” Labour Economics, vol. 7(5), pp. 507-544.

Schuetze, Herbert J. and Bruce, Donald (2004). "Tax Policy and Entrepreneurship." Swedish Economic Policy Review, vol. 11(2), pp. 233-265.

Torrini, Roberto (2005). "Cross-country Differences in Self-employment Rates: The Role of Institutions." Labour Economics, vol. 12(5), pp. 661-683. 


\section{Tables}

Table 1. Average top marginal post-war tax rates in the US and Sweden

\begin{tabular}{lcc}
\hline \hline Variable & US & Sweden \\
\hline Income tax & 65.3 & 69.9 \\
& $(21.82)$ & $(10.49)$ \\
Payroll taxes & 10.4 & 21.6 \\
& $(4.33)$ & $(14.58)$ \\
Corporate income tax & 45.5 & 38.3 \\
& $(6.74)$ & $(7.54)$ \\
Capital gains tax & 27.2 & 40.3 \\
& $(5.50)$ & $(11.22)$
\end{tabular}

Note: Values in parentheses refer to standard deviations. Swedish average figures refer to the time period 1947 to 2007, and US figures refer to 1950 to 1999. Capital gains tax for Sweden refers to unincorporated selfemployed and is an average of short-term (less than 2 years) and long-term (more than 5 years) possessions. The Swedish tax system is described in more detail in section 3.

Table 2. Business form and taxation

\begin{tabular}{llllll}
\hline Business form & $\begin{array}{l}\text { Legal } \\
\text { entity }\end{array}$ & Tax subject & Payroll taxes & $\begin{array}{l}\text { Corporate } \\
\text { income tax }\end{array}$ & Personal income tax \\
\hline $\begin{array}{l}\text { Sole } \\
\text { proprietorship }\end{array}$ & No & No & Yes & No & Business income \\
$\begin{array}{l}\text { Partnership } \\
\text { company }\end{array}$ & Yes & No & Yes & No & Business income \\
$\begin{array}{l}\text { Closely held } \\
\text { incorporated } \\
\text { company }\end{array}$ & Yes & Yes & $\begin{array}{l}\text { Wage: Yes } \\
\text { Dividend: No }\end{array}$ & $\begin{array}{l}\text { Wage: No } \\
\text { Dividend: Yes }\end{array}$ & $\begin{array}{l}\text { Wage: income from } \\
\text { employment } \\
\text { Dividend: Capital } \\
\text { income and income from } \\
\text { employment (after } \\
\text { 1990/91) }\end{array}$ \\
\hline
\end{tabular}


Figure 1. Self-employment rates in Sweden

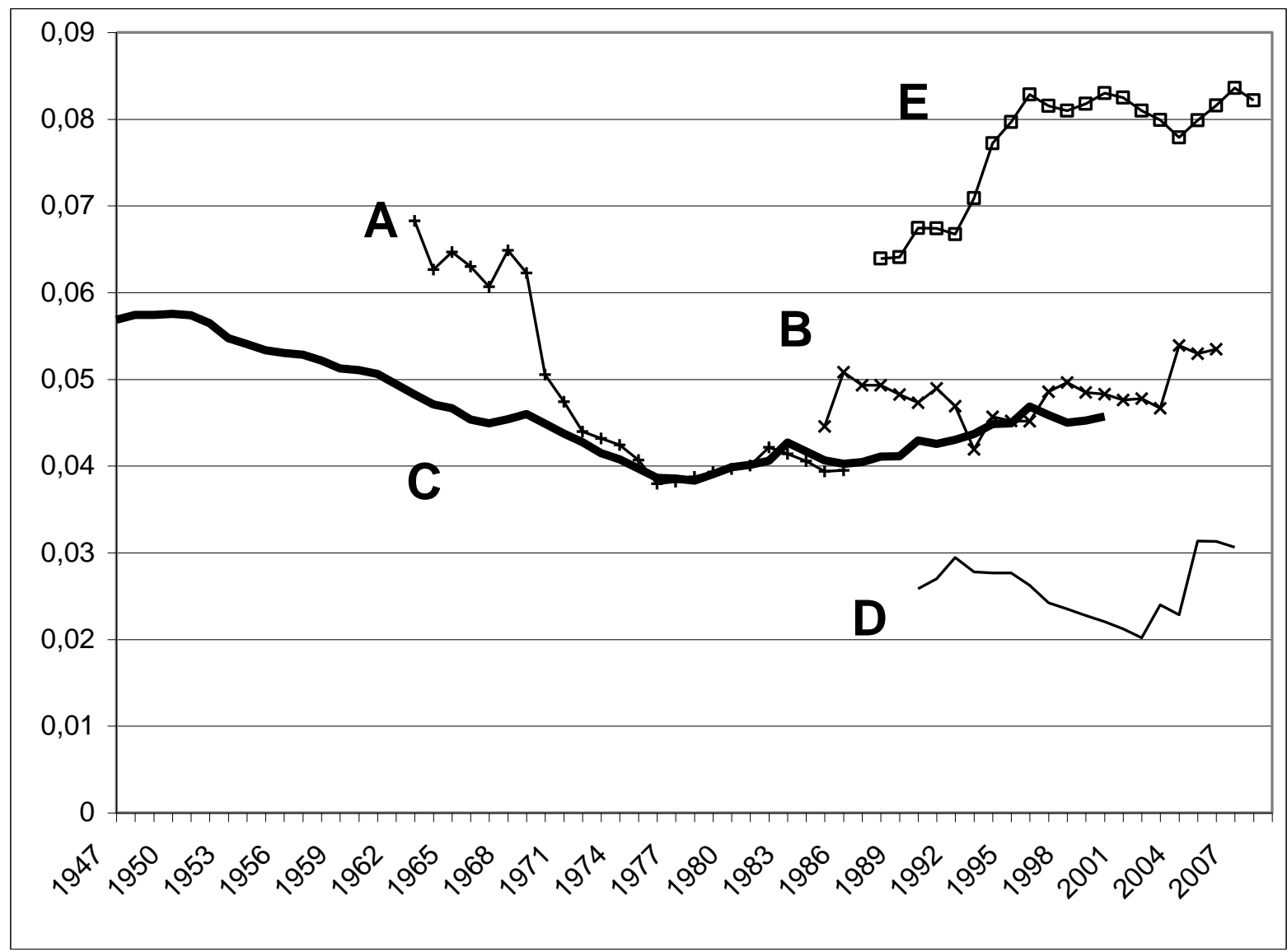

Note: description in table 3.

Table 3. Description of available self-employment rates in Sweden

\begin{tabular}{lll}
\hline \hline Description & Time period & Source \\
\hline $\begin{array}{l}\text { A. Unincorporated self-employment excluding agricultural } \\
\text { sector (percent of labor force) }\end{array}$ & & AKU \\
$\begin{array}{l}\text { B. Unincorporated self-employment including agricultural } \\
\text { sector (percent of labor force) }\end{array}$ & & RAMS, until 2003 only \\
$\begin{array}{l}\text { C. Unincorporated self-employment excluding agricultural } \\
\text { sector (percent of population aged between 16-64) }\end{array}$ & profitable companies \\
$\begin{array}{l}\text { D. Incorporated self-employment including agricultural } \\
\text { sector (percent of labor force) }\end{array}$ & Edvinsson (2005) \\
$\begin{array}{l}\text { E. Total self-employment excluding agricultural sector } \\
\text { (percent of labor force) }\end{array}$ & 1986-2007 & RAMS, until 2003 only \\
\hline
\end{tabular}


Figure 2. Top marginal income tax rate in Sweden, post-war period

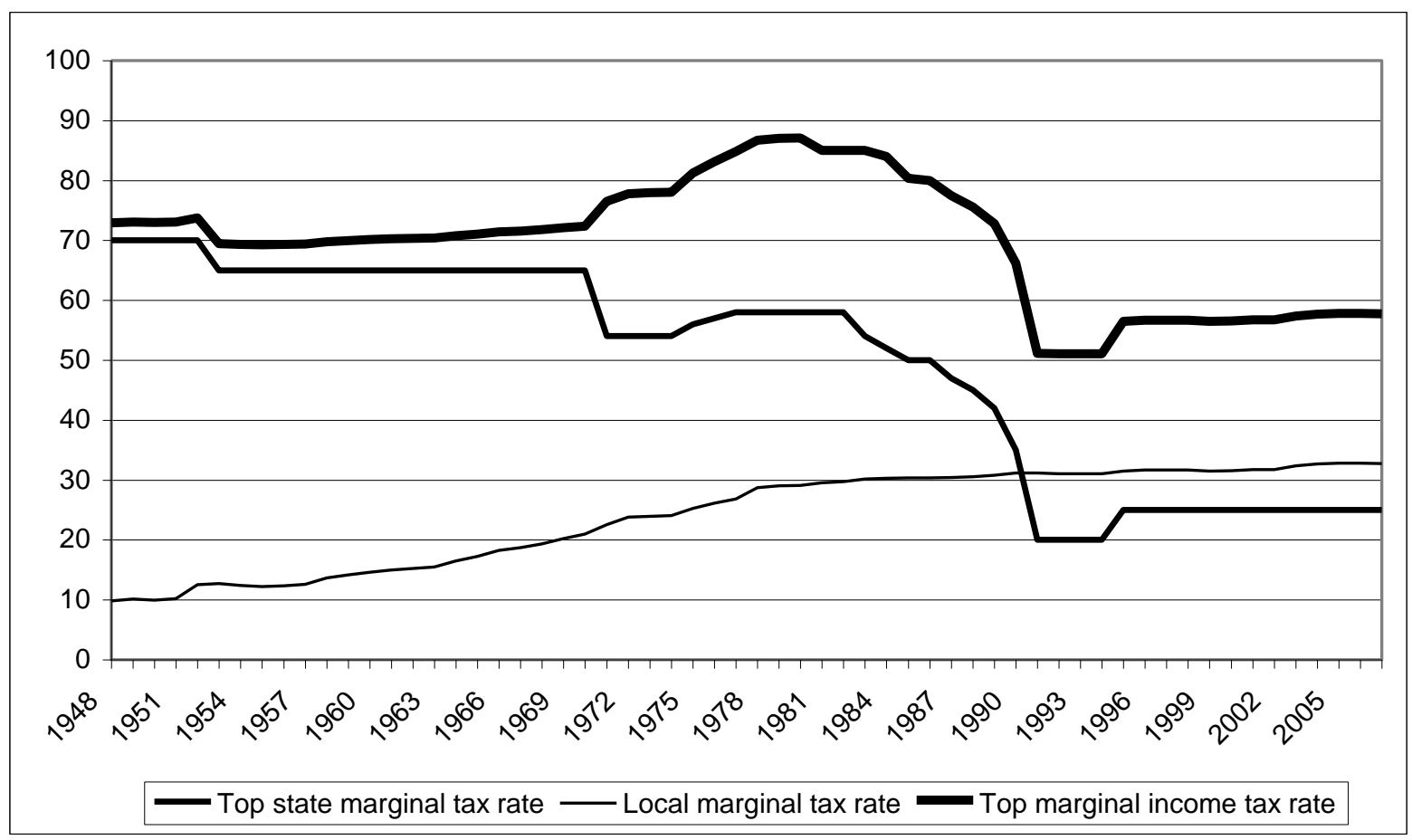

Figure 3. Top marginal payroll tax rate in Sweden, post-war period

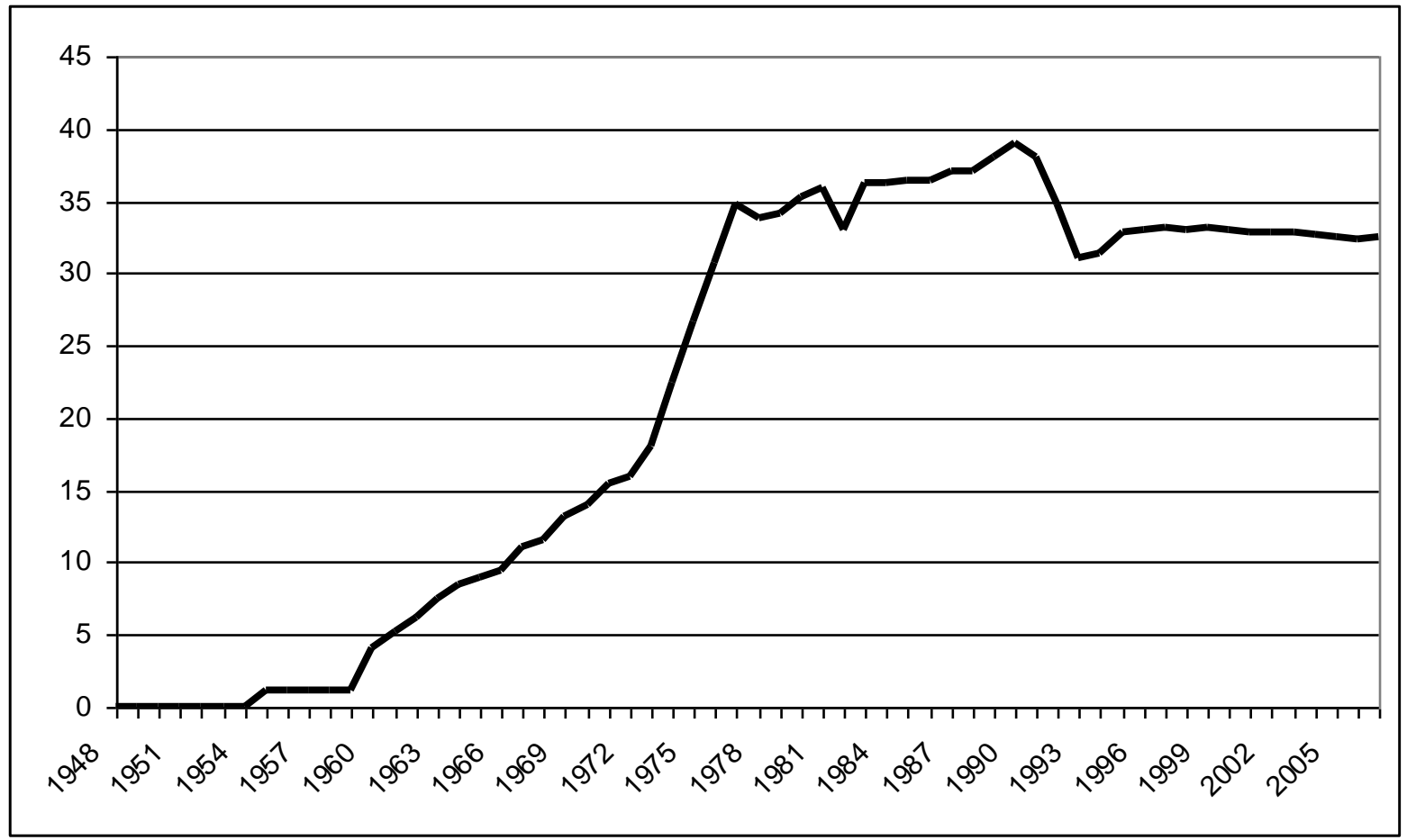


Figure 4. Top marginal capital gains tax rate in Sweden, post-war period

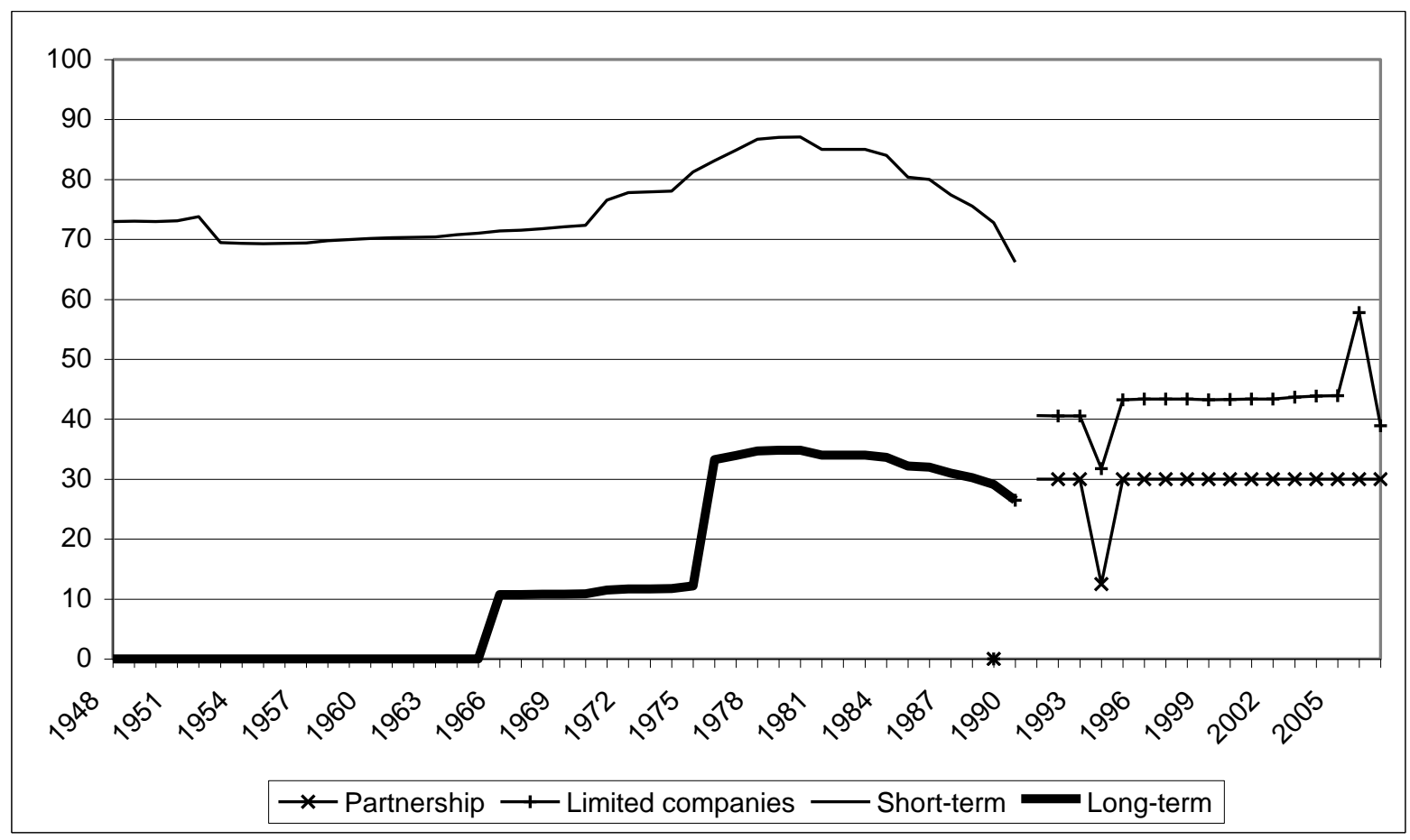

Figure 5. Top marginal corporate income tax rate in Sweden, post-war period

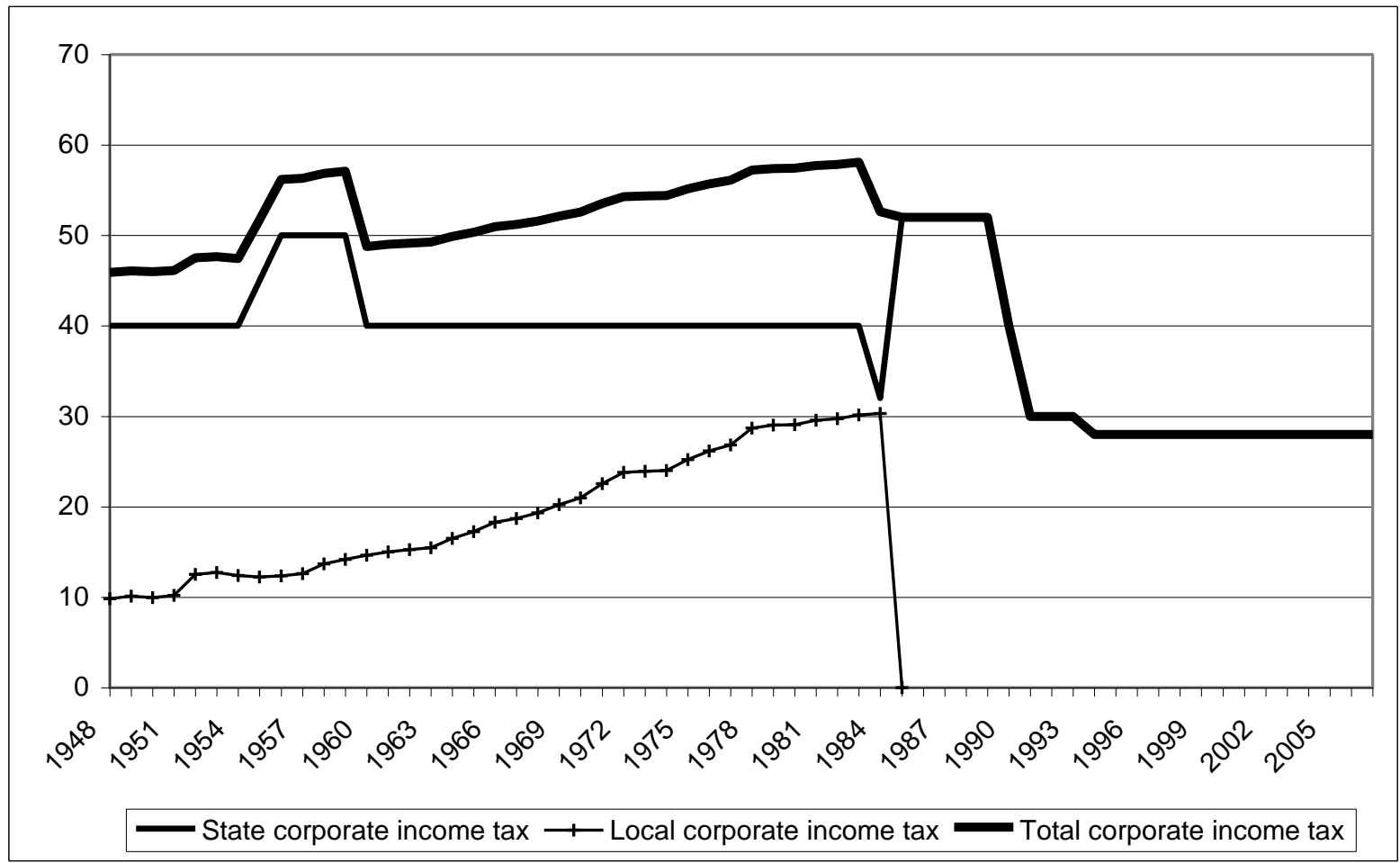


Table 4. Summary of all variables used

\begin{tabular}{|c|c|c|c|c|c|}
\hline Variable & Obs. & Mean & St. dev. & Min & Max \\
\hline \multicolumn{6}{|l|}{ Self-employment: } \\
\hline Dataset A & 24 & 4.798236 & 1.079481 & 3.7948 & 6.82796 \\
\hline Dataset B & 22 & 4.821808 & 0.2914397 & 4.19016 & 5.39107 \\
\hline Dataset C & 54 & 4.622871 & 0.5841237 & 3.831054 & 5.755352 \\
\hline Dataset D & 18 & 2.586833 & 0.3477616 & 2.01901 & 3.13259 \\
\hline Dataset E & 21 & 7.694774 & 0.6911954 & 6.39229 & 8.35986 \\
\hline Corporate income tax & 60 & 38.31667 & 7.54083 & 28 & 52 \\
\hline Income tax & 60 & 69.86316 & 10.4913 & 51.04 & 87.09 \\
\hline Payroll taxes & 60 & 21.64843 & 14.58385 & 0 & 38.97 \\
\hline $\begin{array}{l}\text { Capital gains tax } \\
\text { Short-run, inc. }\end{array}$ & 60 & 66.23516 & 15.9233 & 31.775 & 87.09 \\
\hline $\begin{array}{l}\text { Capital gains tax } \\
\text { Long-run, inc. }\end{array}$ & 60 & 22.14411 & 18.11799 & 0 & 57.8 \\
\hline $\begin{array}{l}\text { Capital gains tax } \\
\text { Short-run, noninc. }\end{array}$ & 60 & 62.31049 & 21.87386 & 12.5 & 87.09 \\
\hline $\begin{array}{l}\text { Capital gains tax } \\
\text { Long-run, noninc. }\end{array}$ & 60 & 18.21944 & 14.18537 & 0 & 34.836 \\
\hline Wealth tax abolition & 60 & 0.7333333 & 0.4459485 & 0 & 1 \\
\hline Ln (Average wage) & 60 & 7.049723 & 0.3047636 & 6.359574 & 7.560499 \\
\hline Unemployment rate & 61 & 3.208197 & 1.923564 & 1.2 & 8.2 \\
\hline $\begin{array}{l}\text { Female participation } \\
\text { rate }\end{array}$ & 45 & 44.82976 & 4.019752 & 36.79397 & 48.09075 \\
\hline Services sector share & 61 & 62.20801 & 10.29278 & 47.29858 & 77.72182 \\
\hline Average age & 60 & 37.46396 & 1.834903 & 34.25835 & 40.40963 \\
\hline Interest rate & 61 & 6.133668 & 3.342065 & 1.709533 & 14.76213 \\
\hline $\begin{array}{l}\text { Ln (Stock of wealth), } \\
\text { Englund }\end{array}$ & 41 & 9.191585 & 0.4930522 & 8.28804 & 9.936195 \\
\hline $\begin{array}{l}\text { Ln (Stock of wealth), } \\
\text { Statistics Sweden }\end{array}$ & 28 & 10.46877 & 0.8294469 & 9.124455 & 11.66906 \\
\hline Government & 61 & 0.1803279 & 0.3876509 & 0 & 1 \\
\hline
\end{tabular}


Table 5. Description of the control variables

\begin{tabular}{|c|c|c|}
\hline Control variable & Definition & Source, period \\
\hline Growth level & GDP growth / year & $\begin{array}{l}\text { Lund University Macroeconomic } \\
\text { and Demographic Database } \\
\qquad 1947-1950 \\
\text { Statistics Sweden 1951- }\end{array}$ \\
\hline Average wage & $\begin{array}{l}\text { Real average wage in the } \\
\text { manufacturing and extraction } \\
\text { industry }\end{array}$ & $\begin{array}{c}\text { Statistics Sweden } \\
\text { Whole period, except } 2007\end{array}$ \\
\hline Unemployment rate & $\begin{array}{c}\text { Open unemployment as a } \\
\text { share of labor force (16-64) }\end{array}$ & $\begin{array}{l}\text { Statistics Sweden } \\
\text { Whole period }\end{array}$ \\
\hline Female participation rate & $\begin{array}{l}\text { Percent of labor force (16-64) } \\
\text { that is female }\end{array}$ & $\begin{array}{c}\text { Statistics Sweden } \\
1963-\end{array}$ \\
\hline Services sector share & $\begin{array}{l}\text { Percent of labor force (16-64) } \\
\text { that is in the services sector }\end{array}$ & $\begin{array}{c}\text { Statistics Sweden } \\
1987- \\
\text { Edvinsson }(2005) \\
1947-2000\end{array}$ \\
\hline Average age & Average age of population & $\begin{array}{c}\text { Statistics Sweden } \\
\text { Whole period, except } 2007\end{array}$ \\
\hline Interest rate & $\begin{array}{c}\text { Short-run yield } \\
\text { (30 days treasure yield) }\end{array}$ & $\begin{array}{l}\text { Swedish Riksbank } \\
\text { Whole period }\end{array}$ \\
\hline Stock of wealth & $\begin{array}{l}\text { Total real wealth among } \\
\text { households / population }\end{array}$ & $\begin{array}{l}\text { Englund (1993) 1950-1990 } \\
\text { Statistics Sweden 1980-2007 }\end{array}$ \\
\hline Government & $\begin{array}{l}\text { Dummy for years with a } \\
\text { non-social democratic } \\
\text { government }\end{array}$ & Whole period \\
\hline
\end{tabular}


Table 6. Time-series regression results

\begin{tabular}{|c|c|c|c|c|c|}
\hline Dataset & A & $\mathrm{B}$ & $\mathrm{C}$ & $\mathrm{D}$ & $\bar{E}$ \\
\hline Unincorporated/incorporated/total & $\mathrm{U}$ & $\mathrm{U}$ & $\mathrm{U}$ & I & $\mathrm{T}$ \\
\hline Time period & $63-86$ & $85-06$ & $47-00$ & $89-06$ & $86-07$ \\
\hline Top corporate income tax rate & $\begin{array}{c}-0.0476^{* *} * \\
(0.027)\end{array}$ & $\begin{array}{c}0.0672 * \\
(0.091)\end{array}$ & $\begin{array}{c}-0.0069 * * \\
(0.038)\end{array}$ & $\begin{array}{l}0.0730 \\
(0.935)\end{array}$ & $\begin{array}{c}-0.0591 * * \\
(0.039)\end{array}$ \\
\hline Top income tax rate & $\begin{array}{c}-0.0414 \\
(0.554)\end{array}$ & $\begin{array}{c}-0.1198 \\
(0.172)\end{array}$ & $\begin{array}{c}-0.00787 \\
(0.562)\end{array}$ & $\begin{array}{c}-0.1528 \\
(0.950)\end{array}$ & $\begin{array}{c}0.0991 * * \\
(0.015)\end{array}$ \\
\hline Top payroll tax rate & $\begin{array}{l}0.0335 \\
(0.527)\end{array}$ & $\begin{array}{c}-0.1148 \\
(0.676)\end{array}$ & $\begin{array}{c}-0.0156^{*} \\
(0.084)\end{array}$ & $\begin{array}{c}-0.3408 \\
(0.824)\end{array}$ & $\begin{array}{l}0.1022 \\
(0.395)\end{array}$ \\
\hline Top capital gain tax rate (short) & - & $\begin{array}{l}0.0093 \\
(0.685)\end{array}$ & $\begin{array}{c}0.00110 \\
(0.899)\end{array}$ & $\begin{array}{l}0.0150 \\
(0.983)\end{array}$ & $\begin{array}{c}-0.0064 \\
(0.387)\end{array}$ \\
\hline Top capital gain tax rate (long) & $\begin{array}{c}0.0439 * \\
(0.059)\end{array}$ & $\begin{array}{c}-0.0737 \\
(0.118)\end{array}$ & $\begin{array}{c}0.00818 \\
(0.199)\end{array}$ & $\begin{array}{c}-0.0090 \\
(0.983)\end{array}$ & $\begin{array}{c}0.0803 * * \\
(0.024)\end{array}$ \\
\hline Wealth tax exclusion & - & $\begin{array}{c}-0.2797 \\
(0.677)\end{array}$ & $\begin{array}{c}0.2869 * * * \\
(0.003)\end{array}$ & $\begin{array}{l}-2.237 \\
(0.759)\end{array}$ & $\begin{array}{l}0.4931 \\
(0.345)\end{array}$ \\
\hline Ln (Real average wage rate) & $\begin{array}{c}-0.5304 \\
(0.835)\end{array}$ & $\begin{array}{l}-23.08 \\
(0.285)\end{array}$ & $\begin{array}{c}-1.915 * * * \\
(0.000)\end{array}$ & $\begin{array}{c}4.116 \\
(0.965)\end{array}$ & $\begin{array}{l}26.78^{*} \\
(0.050)\end{array}$ \\
\hline Ln (Wealth) & $\begin{array}{c}8.189 * * * \\
(0.005)\end{array}$ & $\begin{array}{c}1.227 \\
(0.421)\end{array}$ & - & $\begin{array}{c}-0.5440 \\
(0.936)\end{array}$ & $\begin{array}{l}-1.355 \\
(0.138)\end{array}$ \\
\hline Real GDP growth rate & $\begin{array}{c}-0.1071 \\
(0.162)\end{array}$ & $\begin{array}{l}0.0918 \\
(0.311)\end{array}$ & $\begin{array}{c}0.003557 \\
(0.754)\end{array}$ & $\begin{array}{l}0.0923 \\
(0.519)\end{array}$ & $\begin{array}{c}0.0322^{*} \\
(0.083)\end{array}$ \\
\hline Unemployment rate & $\begin{array}{l}0.6247 \\
(0.301)\end{array}$ & $\begin{array}{l}0.4232 \\
(0.180)\end{array}$ & $\begin{array}{c}-0.06899 * * \\
(0.014)\end{array}$ & $\begin{array}{l}0.4080 \\
(0.766)\end{array}$ & $\begin{array}{c}-0.3953^{* *} \\
(0.028)\end{array}$ \\
\hline Service sector share & $\begin{array}{c}-0.9330 \\
(0.134)\end{array}$ & $\begin{array}{l}-1.185 \\
(0.103)\end{array}$ & $\begin{array}{c}0.03015 \\
(0.262)\end{array}$ & $\begin{array}{c}-0.5722 \\
(0.853)\end{array}$ & $\begin{array}{l}1.052 * * \\
(0.023)\end{array}$ \\
\hline Interest rate & $\begin{array}{l}0.0509 \\
(0.452)\end{array}$ & $\begin{array}{l}0.3100 \\
(0.173)\end{array}$ & $\begin{array}{c}-0.03235^{* * * *} \\
(0.003)\end{array}$ & $\begin{array}{l}0.2834 \\
(0.789)\end{array}$ & $\begin{array}{c}-0.3495^{* *} \\
(0.044)\end{array}$ \\
\hline Average age & $\begin{array}{c}6.736 * * \\
(0.013)\end{array}$ & $\begin{array}{c}10.03 \\
(0.143)\end{array}$ & $\begin{array}{c}-0.2531 * \\
(0.068)\end{array}$ & $\begin{array}{c}2.848 \\
(0.901)\end{array}$ & $\begin{array}{c}-11.42 * * \\
(0.020)\end{array}$ \\
\hline Female share & $\begin{array}{l}0.3194 \\
(0.401)\end{array}$ & $\begin{array}{c}1.997 \\
(0.148)\end{array}$ & - & $\begin{array}{l}0.4196 \\
(0.940)\end{array}$ & $\begin{array}{c}-2.319 * * \\
(0.030)\end{array}$ \\
\hline Non-social democratic government & $\begin{array}{c}-0.6103 * \\
(0.095)\end{array}$ & $\begin{array}{l}0.0154 \\
(0.945)\end{array}$ & $\begin{array}{c}-0.2265^{* *} \\
(0.020)\end{array}$ & $\begin{array}{c}-0.3458 \\
(0.980)\end{array}$ & $\begin{array}{l}0.1505 \\
(0.160)\end{array}$ \\
\hline Time trend & $\begin{array}{c}-0.7095 * * \\
(0.036)\end{array}$ & $\begin{array}{l}0.2421 \\
(0.345)\end{array}$ & $\begin{array}{c}0.02229 \\
(0.468)\end{array}$ & $\begin{array}{l}0.1086 \\
(0.977)\end{array}$ & $\begin{array}{c}-0.0770 \\
(0.528)\end{array}$ \\
\hline Constant & $\begin{array}{c}-254.9 * * \\
(0.024)\end{array}$ & $\begin{array}{l}-250.0 \\
(0.147)\end{array}$ & $\begin{array}{c}26.63 * * * \\
(0.000)\end{array}$ & $\begin{array}{l}-104.4 \\
(0.885)\end{array}$ & $\begin{array}{c}309.6^{* *} \\
(0.018)\end{array}$ \\
\hline$\frac{\mathrm{N}}{\mathrm{R}^{2}}$ & $\begin{array}{c}24 \\
0.9785\end{array}$ & $\begin{array}{c}22 \\
0.8942\end{array}$ & $\begin{array}{c}53 \\
0.9781\end{array}$ & $\begin{array}{c}18 \\
0.9508\end{array}$ & $\begin{array}{c}20 \\
0.9993\end{array}$ \\
\hline D-W Statistics & 2.084963 & 2.263109 & 1.461119 & 3.072843 & 3.014351 \\
\hline
\end{tabular}




\begin{tabular}{|c|c|c|}
\hline Variable & ADF & $\begin{array}{c}\text { ADF } \\
\text { alternative }\end{array}$ \\
\hline A. In levels & & with trend \\
\hline Self-employment (dataset C) & -2.171 & 0.132 \\
\hline Top corporate income tax rate & -1.749 & -2.607 \\
\hline Top income tax rate & -0.606 & -1.091 \\
\hline Top payroll tax rate & -1.475 & 0.060 \\
\hline Top capital gain tax rate (short) & -0.552 & -1.455 \\
\hline Top capital gain tax rate (long) & -1.422 & -2.234 \\
\hline Ln (Real average wage rate) & -1.911 & -1.841 \\
\hline Real GDP growth rate & $-5.526^{*}$ & $-5.664 *$ \\
\hline Unemployment rate & -1.330 & -1.977 \\
\hline Service sector share & 0.066 & -1.634 \\
\hline Interest rate & -1.806 & -1.558 \\
\hline Average age & -1.171 & -1.015 \\
\hline B. First differences & & with constant \\
\hline Self-employment (dataset C) & $-4.727 *$ & $-4.915^{*}$ \\
\hline Top corporate income tax rate & $-7.682^{*}$ & $-7.637 *$ \\
\hline Top income tax rate & $-4.994^{*}$ & $-4.987 *$ \\
\hline Top payroll tax rate & $-4.322 *$ & $-4.681 *$ \\
\hline Top capital gain tax rate (short) & $-7.601 *$ & $-7.654 *$ \\
\hline Top capital gain tax rate (long) & $-9.619 *$ & $-9.700 *$ \\
\hline Ln (Real average wage rate) & $-4.313 *$ & $-5.248^{*}$ \\
\hline Real GDP growth rate & $-9.867 *$ & $-9.778 *$ \\
\hline Unemployment rate & $-4.193 *$ & $-4.153 *$ \\
\hline Service sector share & $-3.042 *$ & $-4.902 *$ \\
\hline Interest rate & $-8.874 *$ & $-8.797 *$ \\
\hline Average age & -0.897 & -2.090 \\
\hline
\end{tabular}


Table 8. Final OLS regression based on dataset C

\begin{tabular}{|c|c|}
\hline Dependent variable & \\
\hline \multirow[t]{2}{*}{ Top corporate income tax rate } & $-0.00970 * * *$ \\
\hline & $(0.006)$ \\
\hline \multirow[t]{2}{*}{ Top payroll tax rate } & $-0.0191 * * *$ \\
\hline & $(0.007)$ \\
\hline \multirow[t]{2}{*}{ Wealth tax exclusion } & $0.3525^{* * *}$ \\
\hline & $(0.004)$ \\
\hline \multirow[t]{2}{*}{ Ln (Real average wage rate) } & $-2.0342 * * *$ \\
\hline & $(0.000)$ \\
\hline \multirow[t]{2}{*}{ Unemployment rate } & $-0.0662 * * *$ \\
\hline & $(0.007)$ \\
\hline \multirow[t]{2}{*}{ Service sector share } & $0.03986 * * *$ \\
\hline & $(0.006)$ \\
\hline \multirow[t]{2}{*}{ Interest rate } & $-0.03476 * * *$ \\
\hline & $(0.000)$ \\
\hline \multirow[t]{2}{*}{ Non-social democratic government } & $-0.1455 * * *$ \\
\hline & $(0.008)$ \\
\hline \multirow[t]{2}{*}{ Constant } & $17.97 * * *$ \\
\hline & $(0.000)$ \\
\hline $\mathrm{N}$ & 53 \\
\hline$\overline{\mathrm{R}}^{2}$ & 0.9724 \\
\hline D-W Statistics & 1.28021 \\
\hline
\end{tabular}


Table 9. Johansen-Juselius' multiple cointegration test results

\begin{tabular}{ccc}
\hline \hline $\begin{array}{c}\mathrm{H}_{0} \text { : order of } \\
\text { cointegration }\end{array}$ & $\begin{array}{c}\text { Maximum } \\
\text { Eigenvalue } \\
\text { test }\end{array}$ & Trace test \\
\hline $\mathrm{r}=0$ & $60.0005^{*}$ & $169.59^{*}$ \\
$\mathrm{r} \leq 1$ & 34.7830 & $109.59^{*}$ \\
$\mathrm{r} \leq 2$ & 24.6855 & $74.81^{*}$ \\
$\mathrm{r} \leq 3$ & 20.8153 & $50.12^{*}$ \\
$\mathrm{r} \leq 4$ & 15.9401 & 29.31 \\
$\mathrm{r} \leq 5$ & 11.8700 & 13.37 \\
$\mathrm{r} \leq 6$ & 1.4959 & 1.50
\end{tabular}

Note: $r$ denotes the number of cointegrating vectors.

The null hypothesis in the Maximum Eigenvalue test is that there are exactly $r$ cointegrating vectors, whereas the null hypothesis in the Trace test is that there are at most $r$ cointegrating vectors.

The cointegration test above includes the possibility of a constant in both the long- and short-run relationships. An asterisk indicates rejection of the relevant null at the 5 per cent level. 
Table 10. Long-run relationship based on cointegration analysis

\begin{tabular}{cc}
\hline \hline Variable & $\begin{array}{c}\text { Self- } \\
\text { employment } \\
\text { rate }\end{array}$ \\
\hline Top corporate income tax rate & $-0.0119 * * *$ \\
$(0.000)$ \\
Top payroll tax rate & $-0.0315^{* * *}$ \\
Ln (Real average wage rate) & $(0.000)$ \\
& $-2.209 * * *$ \\
Unemployment rate & $(0.000)$ \\
& -0.0233 \\
Service sector share & $(0.247)$ \\
& $0.0659 * * *$ \\
Interest rate & $(0.000)$ \\
Constant & $-0.0321 * * *$ \\
& $(0.000)$ \\
& 17.43 \\
& $()$.
\end{tabular}

Note: $P$-values in parentheses. One (two; three) asterisk(s) indicates statistical significance at the $10(5 ; 1)$ per cent level. 
Table 11. Short-run error-correction model

\begin{tabular}{cc}
\hline \hline Variable & $\begin{array}{c}\Delta \text { Self- } \\
\text { employment } \\
\text { rate }\end{array}$ \\
\hline$\Delta$ Self-employment rate, lagged & $0.354^{* *}$ \\
$(0.013)$ \\
$\Delta$ Top corporate income tax rate, & 0.00179 \\
lagged & $(0.521)$ \\
$\Delta$ Top payroll tax rate, lagged & -0.0125 \\
& $(0.153)$
\end{tabular}

$\Delta$ Real average wage rate, lagged

$-0.0000947$

(0.771)

$\Delta$ Unemployment rate, lagged $\quad-0.0118$

(0.604)

$\Delta$ Service sector share, lagged $\quad 0.00476$

(0.860)

$\Delta$ Interest rate, lagged

0.00597

(0.478)

$\Delta \mathrm{Ln}$ (Real average wage rate), $\quad 0.00708$

lagged (0.984)

Error correction term, lagged $\quad-0.284^{* *}$

(0.018)

$\begin{array}{lr}0.00721 \\ \text { Constant } & (0.707)\end{array}$

$\mathrm{N}$

51

$\overline{\mathrm{R}}^{2}$

0.3781

Note: $P$-values in parentheses. One (two; three) asterisk(s) indicates statistical significance at the $10(5 ; 1)$ per cent level. 